\title{
SIRT2 wt Allele
}

National Cancer Institute

\section{Source}

National Cancer Institute. SIRT2 wt Allele. NCI Thesaurus. Code C101563.

Human SIRT 2 wild-type allele is located in the vicinity of $19 q 13$ and is approximately $21 \mathrm{~kb}$ in length. This allele, which encodes NAD-dependent deacetylase sirtuin-2 protein, is involved in the regulation of protein acetylation. 